\title{
年間特集「超」: 総合論文
}

\section{マイクロ血管モデルの構築と分析化学的応用}

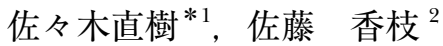

\begin{abstract}
マイクロ流路を用いて血管モデルを構築し，分析化学的応用を図ってきた。電池及び制御系が組み込まれ た小型ポンプを用い，手のひらサイズの細胞培養システムを開発した。これを用いて血管内皮細胞を流路内 で培養し，シリンジポンプを用いた系と同等の細胞増殖速度及びタンパク質発現を実現した．さらに，血管 に加えてリンパ管の要素を有するモデルを作製し，血管及びリンパ管のバリア機能の評価に利用できること を示した．これをハブ毒のアッセイに応用し，分析時間を 24 時間から 30 分に短縮できた，一方，生体内の 現象を精密に理解するために, 細胞を全く用いずに血管構造を再現することを着想した，ナノ粒子を用いる 薬物送達研究への応用を目指し，ナノ粒子の血管壁透過性を無細胞系で評価した．さらに，血管周囲に存在 する間質のモデルも作製し，ナノ粒子の間質透過性を定量評価した。これらは in vivo 分析と in vitro 分析と をつなぐ新たな生体モデルとして，幅広い応用が期待できる.
\end{abstract}

\section{1 緒言}

微細加工技術により作製したマイクロ流体デバイスを用 いる研究は, この 20 年余りの間に大きな進化を遂げてき た。その発端を振り返れば, 1979 年に Terryらによってガ スクロマトグラフィーのミクロ集積化が報告され $れ^{1)}$ ，その 後1990年にManzらによって液体クロマトグラフィーのミ クロ集積化が報告され²), Micro Total Analysis Systems ( $\mu \mathrm{TAS})$ の提唱 ${ }^{3}$ へとつながっている. したがって, マイク 口流体デバイスを用いる研究の源流は分析化学にある。 そ の後, 本分野は化学にとどまらず, 生物学や医学を始めと する様々な学問分野へと守備範囲を広げ，今日に至ってい る. 本分野の現状に関しては総説を参照された(い) 10$)$.

マイクロ流体デバイスの一つの応用として, マイクロ流 路内に細胞を培養して実験する試みが 2000 年頃から取り 組まれてきた．特に，流路内に血管内皮細胞を培養するこ とで，血管と同等のサイズを有する空間において，血流に 相当する溶液流れ下で害験できる。このような実験系は, 培養フラスコのようにサイズが大きく静置培養が基本の系 と比べて, 生体内の環境に近くアッセイ系として有用と考 えられる. 本稿では, このようなマイクロ血管モデルに関 する著者のこれまでの取り組みを中心に紹介する.

\footnotetext{
*E-mail : nsasaki@toyo.jp

${ }^{1}$ 東洋大学理工学部応用化学科 : 350-8585 埼玉県川越市鯨井 2100

${ }^{2}$ 日本女子大学理学部物質生物科学科 : 112-8681 東京都文京区 目白台 2-8-1
}

2 手のひらサイズの細胞培養システム ${ }^{11)}$

\section{$2 \cdot 1$ はじめに}

マイクロ流路内に細胞を培養する従来の研究では，一般 にマイクロ流体デバイスに比べて大型のポンプを接続して 用いる必要があり, システム全体の小型化が困難である. 小型のポンプを組み込んだシステムも存在するが ${ }^{12) ~ 14), ~}$ 装置構成が複雑, 長期培養には外部電源が必要といった問 題を有する，そこで本研究では，小型ポンプを組み込んだ 手のひらサイズの培養システムを開発することとした，す なわち, 電池で駆動されかつ制御系も組み込まれた小型ポ ンプを用いることで, 外部電源や制御を必要としない培養 システムが開発できると考え，以下の研究に取り組んだ.

\section{$2 \cdot 2$ 実験及び結果}

血管内皮細胞は，株化細胞であるヒト皮膚微小血管内皮 細胞（HMEC-1），及び正常細胞であるヒ卜臍帯静脈内皮細 胞（HUVEC）を用いた．マイクロ流路パターン（幅 300 $\mu \mathrm{m}$, 深さ $67 \mu \mathrm{m})$ を有するポリジメチルシロキサン （PDMS）基板をソフトリソグラフィにより作製し，これを 培養血に貼りつけてマイクロ流体デバイスとした．培養中 に気泡が混入するのを防ぐため, 既報 ${ }^{15}$ に従い流路の入り 口に気泡トラップを設置した，流路内に細胞懸濁液を導入 し, $\mathrm{CO}_{2}$ インキュベーター内で 5 時間静置して細胞を流路 底部に接着させた。その後, 小型篧流ポンプ（SMP101-L, プライムテック製) をデバイスに接続し， $6.0 \mu \mathrm{L} \mathrm{h}^{-1}$ で培 地を送液して培養した。対照実験として, シリンジポンプ を用いたマイクロ流路内での灌流培養, 及び培養フラスコ 
での静置培養にも取り組んだ。

本研究で開発した細胞培養システムの写真を Fig. 1 に示 す. サイズは縦 $57 \mathrm{~mm}$, 横 $87 \mathrm{~mm}$ であり, 外部接続が不 要な培養システムとしては世界最小である。このシステム を用いて流路内に HMEC-1 を培養し, 培養フラスコ, 及び シリンジポンプを用いて灌流したマイクロ流路と同等の細 胞増殖速度を実現した. 同様に HUVECを培養したとこ ろ, シリンジポンプを用いた系と同様に細胞が流れに沿っ て配向した. 加えて, 細胞間の密着結合タンパク質 Claudin-5 を䖺光免疫染色により検出し, シリンジポンプ を用いた系と同様に Claudin-5 が細胞の周囲に局在してい るため, 密着結合が形成されていることを示した（Fig. 2). 本実験系は通常の培養フラスコ等に比べてサイズや流れの 点で血管に近い状況をつくり出しているため, 例えば血管 内皮細胞に作用する薬物候補物質のアッセイに応用するな ど, 創薬分野等への幅広い展開が期待できる.

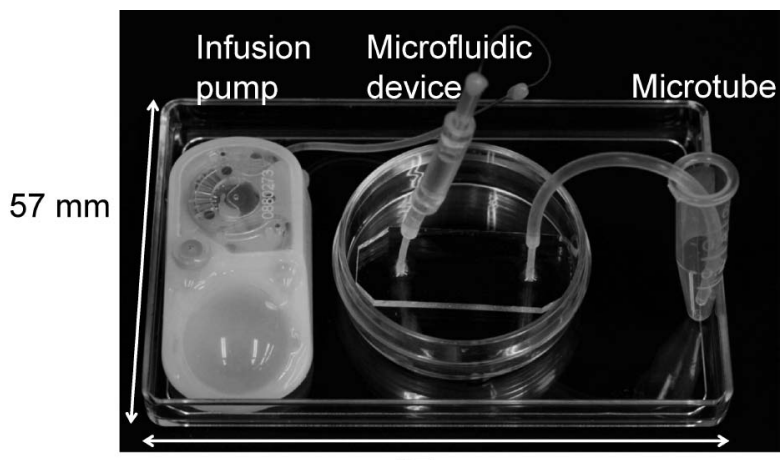

$87 \mathrm{~mm}$

Fig. 1 Photograph of the palmtop-sized microfluidic cell culture system

Reproduced with permission from Electrophoresis, 33, 1729 (2012).

$$
3 \text { マイクロ微小循環デバイス }{ }^{16)}
$$

\section{$3 \cdot 1$ はじめに}

微小循環は毛細血管や毛細リンパ管, さらにはそれらの 間に位置する間質の総称である．微小循環の異常，特に血 管壁の物質透過性の究進は, 炎症反応や浮腫等に関係して いると考えられている. 同様の現象は腫瘍においてもみら れるが, 一方で腫瘍血管においてはその周囲を壁細胞が覆 い，血管壁の物質透過性を減少させているとの報告もあ $る^{17)}$.このように, 従来の研究では微小循環の生理学的な 機構は十分に解明されておらず, その課題に応える新たな in vitro モデルが必要とされている. 加えて, このような血 管壁の物質透過性に関する知見は, 効果的な抗がん剂治療 を実現する上でも重要であり，科学的興味のみならず実応 用の観点からも新たな方法論の開発が契緊の課題である.

これまでの研究では主に動物実験, さらにはヒト血管の in vivoイメージングなどが行われてきた ${ }^{18) 19)}$.しかし in vivo イメージングは空間分解能が低く, 毛細血管・リン パ管を十分に描像できない ${ }^{19)}$. 培養細胞を用いた実験も広 く行われているが, 系の環境が生体内とは大きく異なる. 対して, マイクロ流体デバイスを用いれば, これまでに述 べてきたように，サイズや溶液流れの点で生体により近い 系を構築できる。これまでにも多くの研究が報告されてい るが，そのほとんどは血管にのみ着目しており，リンパ管 に着目した研究はごくわずかである ${ }^{20) 21)}$. 微小循環の最大 の役割は間質における圧力を一定に保つことであり，これ は血管からの物質透過とリンパ管への物質吸収のバランス によって制御されている. したがって, 微小循環の in vitro モデルを構築するには，血管に加えてリンパ管に相当する 要素が必須である．以上を踏まえ本研究では, 血管とリン パ管の要素を含むマイクロ微小循環モデルの開発に取り組 (a)

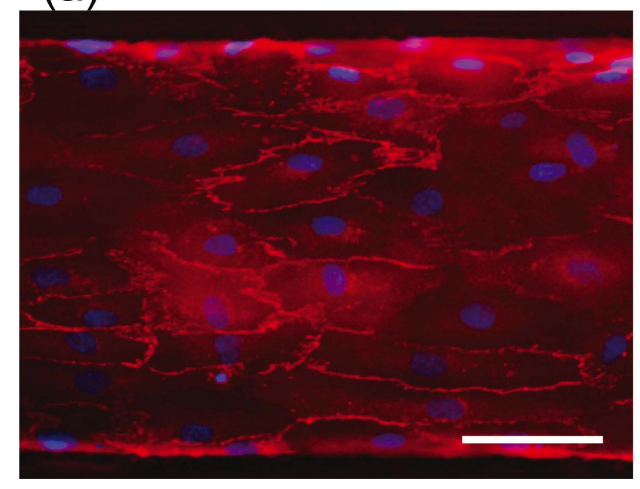

(b)

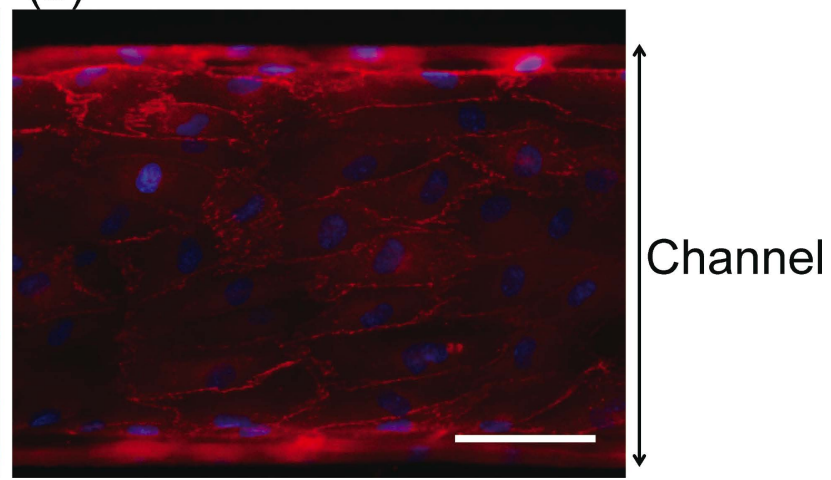

Fig. 2 Immunofluorescence micrographs of HUVEC in a microchannel

Cells were immunostained for Claudin-5 (red, a marker of tight junctions). Nuclei of cells were counterstained with Dapi-Fluoromount-G (blue). (a) HUVEC cultured with a syringe pump. (b) HUVEC cultured with a miniaturized infusion pump. Scale bar: $100 \mu \mathrm{m}$. Reproduced with permission from Electrophoresis, 33, 1729 (2012). 


\section{a}
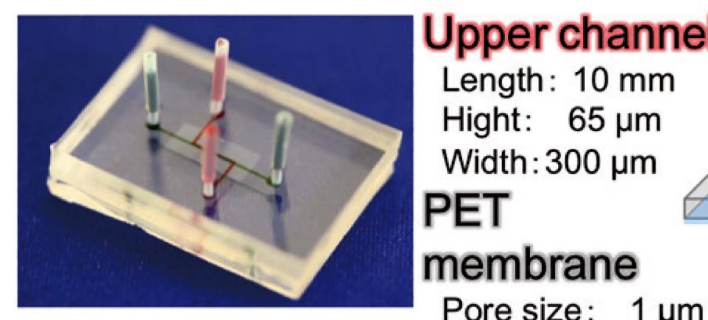

Pore size: $1 \mu \mathrm{m}$ Thickness: $10 \mu \mathrm{m}$

\section{Lower channel}
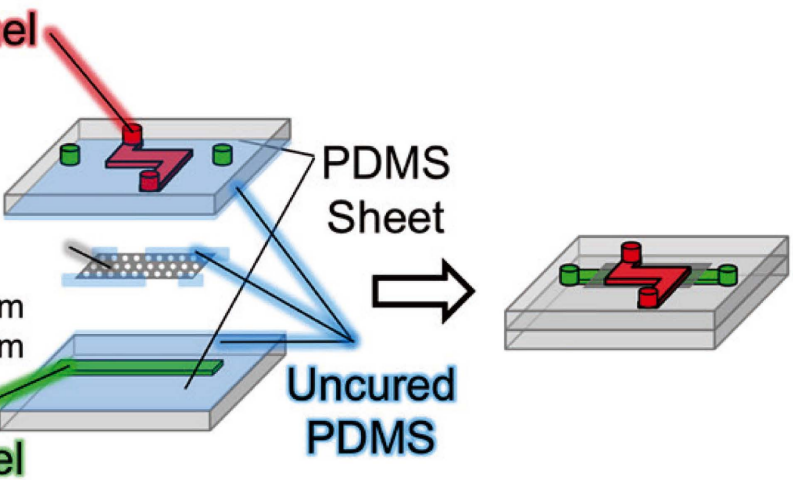

(same size as upper channel)

b

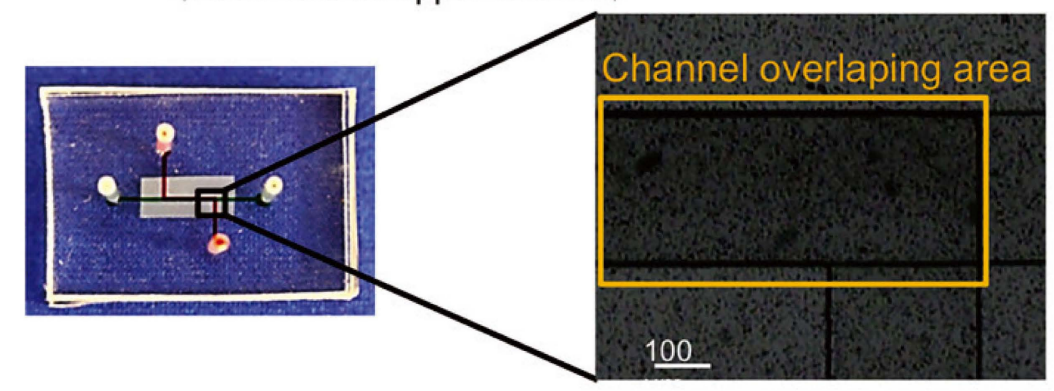

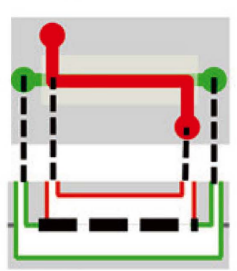

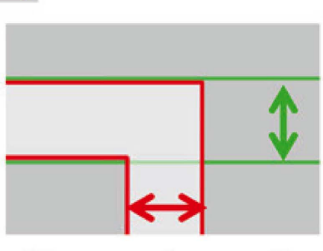

Upper channel

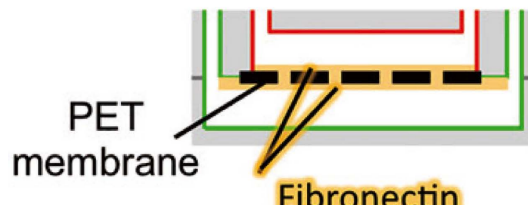

Fibronectin
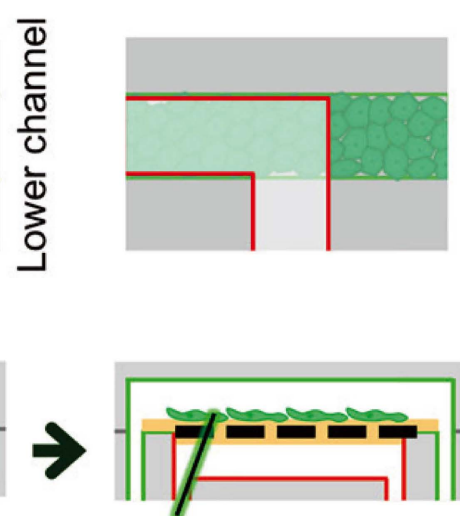

Lymphatic endothelial cells (LECs)

$37^{\circ} \mathrm{C}, 1 \mathrm{~h}$

$37^{\circ} \mathrm{C}, 5 \% \mathrm{CO}_{2}, 24 \mathrm{~h}$

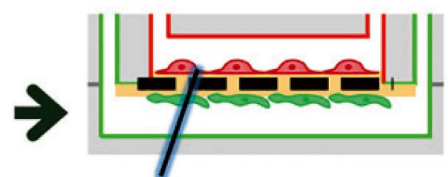

Blood vascular endothelial cells (BECs)

$37^{\circ} \mathrm{C}, 5 \% \mathrm{CO}_{2}, 24 \mathrm{~h}$

Fig. 3 Experimental design, (a) Schematic of a membrane-integrated microfluidic device; (b) Experimental procedure used for coculturing BECs (cells in red) and LECs (cells in green) on opposite sides of the membrane in the microfluidic device

Reproduced with permission from PLoS ONE, 10, e0137301 (2015).

んだ.

\section{$3 \cdot 2$ 実験及び結果}

多孔膜を有するマイクロ流体デバイスは，次章で紹介す
る著者らの既報 ${ }^{22)}$ を基に作製した．多孔膜の上下にマイク 口流路が存在し, 膜越しに細胞を共培養できる設計とした (Fig. 3a)。細胞は正常七ト皮膚微小血管内皮細胞（BEC） 及び正常ヒト微小リンパ管内皮細胞（LEC）を用いた。培 
a

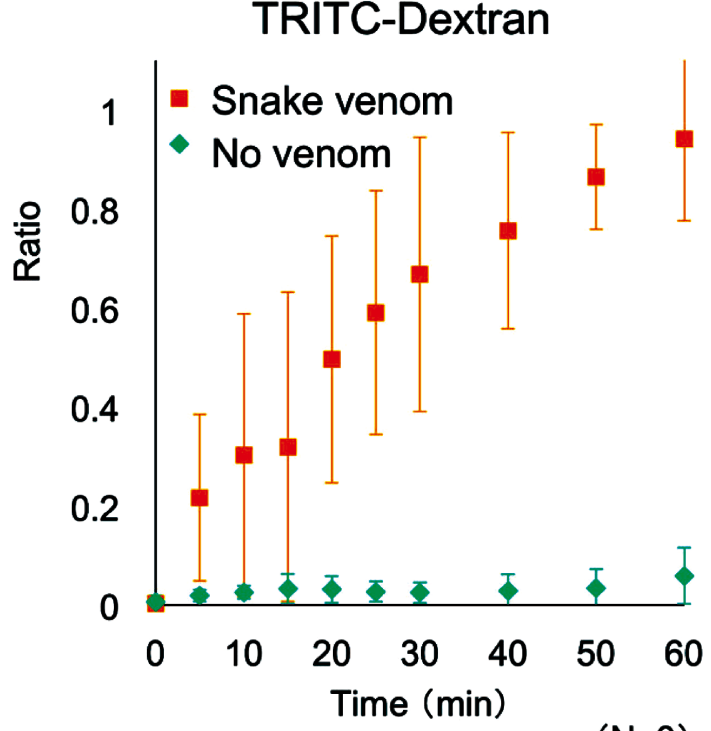

b

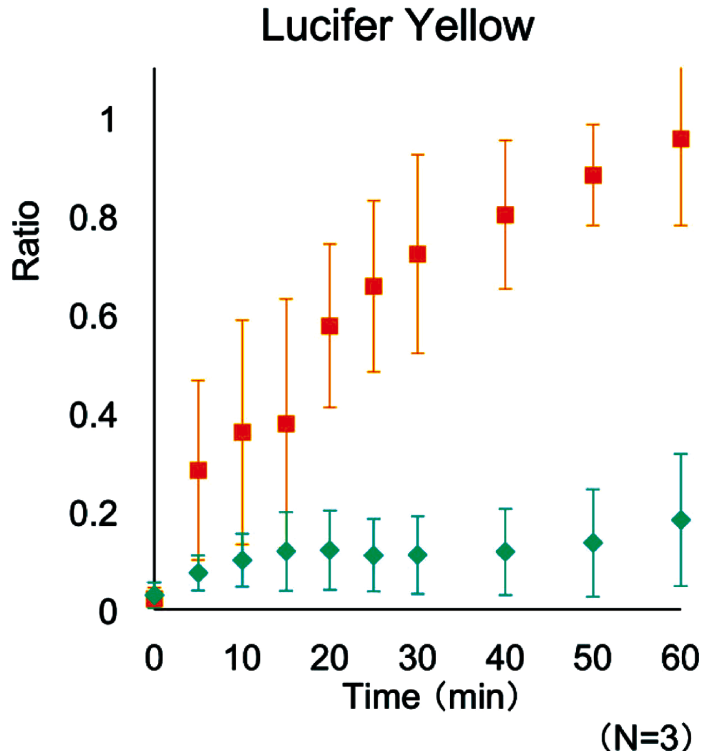

Fig. 4 Permeability of BECs and LECs stimulated with or without habu snake venom

Permeability tests were performed after a 24-h cell culture (BEC-LEC coculture). Samples: (yellow squares) and control (blue diamonds). The values are presented as means \pm SD. The fluorescent tracers used were (a) TRITC-dextran and (b) Lucifer Yellow. The t-test results showed that the 60-min values obtained without (control) and with stimulation with habu snake venom were significantly different: $\mathrm{P}<0.0001$, for both (a) and (b). Each data point was obtained from three devices $(n=3)$. Reproduced with permission from PLoS ONE, 10, e0137301 (2015).

養手順を Fig. 3bに示す. マイクロ流路内壁をフィブロネク チンでコートしたのち, LEC の懸濁液を一方の流路に導入 して多孔膜上に接着させた。デバイスを上下反転させたの ち, もう一方の流路にBECの懸濁液を同様に導入 ・接着さ せたのち, 前章で用いた小型灌流ポンプ, もしくはシリン ジポンプを用いて灌流培養した，免疫染色により，各流路 に目的の細胞がバリア機能を保ったまま培養できているこ とを示した，蛍光標識デキストラン（Dex，分子量40000） 及びルシファーイエロー（LY, 分子量457)を用いて, 多孔 膜上に形成された内皮細胞層の透過性を評価し, 共培養系 とすることでバリア機能が向上すること, 及び灌流培養す ることでもバリア機能が向上することを示した，逆に，刺 激物質の一種であるヒスタミンを添加するとバリア機能は 低下した. 本モデルをハブ毒のアッセイに応用したとこ ろ, ハブ毒の添加によりDex, LY 共に透過量が増加し, 内 皮細胞のバリア機能が低下することを見いだした (Fig. 4). 分析時間は従来法の 24 時間から 30 分に短縮で き，本モデルの分析化学的有用性を示すことができた．本 モデルは生体内の細胞のように流れ刺激を受けた細胞を用 いて, リンパ管内皮細胞が共存する状態で血管内皮細胞層 の透過性を評価しており, 微小循環の機能である血管から の物質透過とリンパ管への物質吸収に相当する過程をマイ クロ流体デバイス上で再現している. 加えて, 経内皮電気
抵抗（TEER）の測定などの電気的手法と異なり, 目的物 を実際に流路に流して透過性を評価できるため, 各種薬剤 の血管透過性の評価に応用可能である.

\section{4 無細胞血管モデル 22$)$}

\section{$4 \cdot 1$ はじめに}

前章までで述べてきたように，マイクロ流路を用いて血 管モデルを構築する場合, 流路内に血管内皮細胞を培養す るのが普通である. しかし, 生体内の現象を精密に理解し ようとする場合には，細胞を用いることすらできない場合 がある．その一例は血管壁の物質透過である．正常血管で は内皮細胞同士が密に結合し, 物質透過を制限している. しかし, 腫瘍血管では血管壁にマイクロ〜ナノサイズの細 胞間隙が存在し，正常血管壁を透過できないナノ粒子も透 過できる（Fig. 5 (a))。この事実は Enhanced permeation and retention (EPR) 現象として広く知られている ${ }^{23) 24)}$.こ のEPR 現象を利用して, 抗がん剂等の薬物をナノ粒子に封 じ込め, 腫瘍血管からのみ漏れ出させてがんに選択的に送 り込む研究が盛んに進められている. しかし, 腫瘍血管壁 に存在する細胞間隙はサイズや形状が不均一である. 加え て，ナノ粒子の血管壁透過の駆動力となる，血管内外の圧 力差も不均一である. すなわち, これらの物理的特性とナ ノ粒子の透過性の関係は, 生体内では明らかにできない. 
(a)

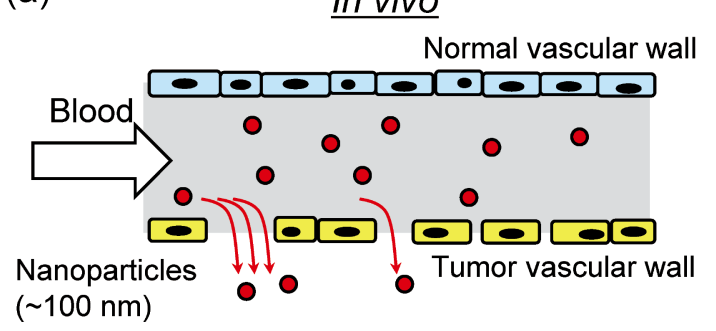

(b)

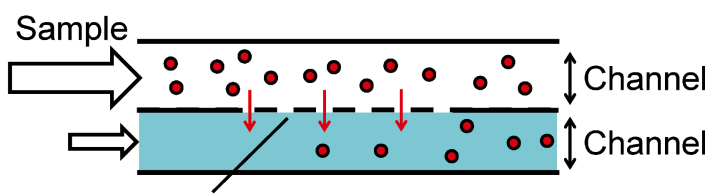

Porous membrane

Fig. 5 (a, b) Schematic illustration of nanoparticle transport (a) in vivo and (b) in this study Reproduced from Proc. Micro Total Analysis Systems, 2013, 1818.

(a)

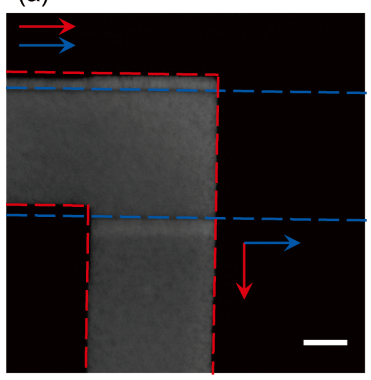

(b)

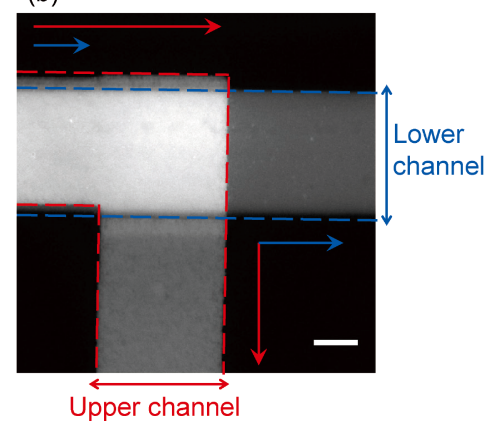

(c)

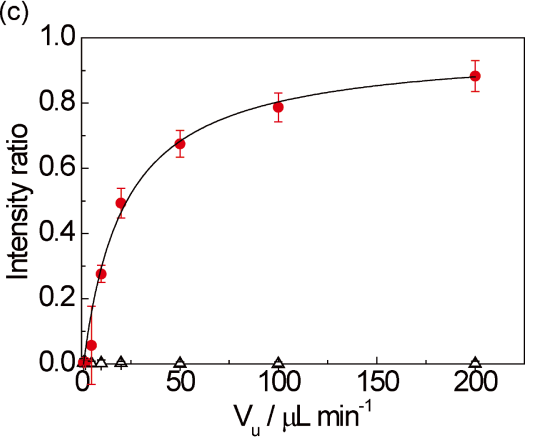

Fig. 6 (a, b) Typical fluorescence micrographs of the microchannels

(a) $V_{\mathrm{u}}=2 \mu \mathrm{L} \min ^{-1} . \quad$ (b) $V_{\mathrm{u}}=200 \mu \mathrm{L} \mathrm{\operatorname {min } ^ { - 1 } .} V_{1}=1 \mu \mathrm{L} \min ^{-1}$. Pore size: $1 \mu \mathrm{m}$. Scale bar: $100 \mu \mathrm{m}$. (c) Dependence of the fluorescence intensity ratio on $V_{\mathrm{u}}$ at different pore size. $\quad$ : $1 \mu \mathrm{m} . \quad \triangle_{\text {: }} 0.1 \mu \mathrm{m} . \quad N=3$. Theoretical lines of the ratio for each pore size are also shown. Reproduced from Proc. Micro Total Analysis Systems, 2013, 1818.

そこで本研究では, 腫瘍血管壁の構造や血管内外の圧力差 を，細胞を用いずに再現したモデルを構築し（Fig. 5 (b)), ナノ粒子の血管壁透過性を無細胞系で明らかにすることと した.

\section{$4 \cdot 2$ 実験及び結果}

腫瘍血管壁のモデルとして市販の多孔膜（孔径 0.1 及び $1.0 \mu \mathrm{m} ）$ を用いた。これを流路パターンを有する 2 枚の PDMS 基板間に挟み，膜越しに流路が上下になるように接 合してマイクロ流体デバイスを作製した，試料には蛍光標 識ポリスチレン粒子（粒径 $0.1 \mu \mathrm{m}$ ）を用いた，上側流路に は試料を含む液を，下側流路には試料を含まない液をそれ ぞれシリンジポンプを用いて送液した. 下側流路の流量 $\left(V_{1}\right)$ を $1 \mu \mathrm{L} \mathrm{min}^{-1}$ に固定し，上側流路の流量（ $\left.V_{\mathrm{u}}\right)$ を $1 \sim 200$ $\mu \mathrm{L} \min ^{-1}$ で変化させて流路の分岐部を顕微蛍光観察した.

多孔膜によって生じる基板間の隙間を埋めるために, 既 報年) を参考に未硬化の PDMS を接合層として用いた．接合 手順を検討することでデバイスを作製できた．このデバイ スを用いてナノ粒子の透過性を評価した結果を Fig. 6 に示 す. 孔径 $0.1 \mu \mathrm{m}$ の膜を用いた場合，上側流路の流量に依 らず, ナノ粒子の透過は見られなかった．これはナノ粒子
の粒径が孔径とほぼ等しいためと考えられる，一方，孔径 $1.0 \mu \mathrm{m}$ の膜を用いた場合, 上側流路の流量が増す，すなわ ち流路間の圧力差が大きくなるとともに下側流路の蛍光輝 度，すなわち粒子の透過量が増大したのち一定值に近づい た.さらにこの圧力差依存性を理論予測と比較した. ここ では, ナノ粒子は剛体球であり, 多孔膜の孔内の流れは ハーゲン・ポアズイユ流であると考えた。ささらに既報 ${ }^{26)}$ と は異なり，拡散ではなく対流によるナノ粒子の孔透過が支 配的であると考えた上で，孔径に対する粒径の比が透過性 に与える影響を補正した ${ }^{27)}$. 実験結果は理論予測と良く一 致し，本モデルを用いてナノ粒子の血管壁透過性に関する 精密評価が可能であることを示した。

$$
5 \text { 無細胞血管一間質複合モデル }{ }^{28)}
$$

\section{$5 \cdot 1$ はじめに}

ナノ粒子を用いる薬物送達においては, ナノ粒子の血管 壁透過後の挙動も重要である. 腫瘍血管とがん細胞の間に は間質が存在し，脺がん等の難治がんにおいてはこの間質 がナノ粒子の腫瘍への輸送を妨げていると言われている. したがって, 腫瘍への効率的な薬物送達を実現するには, ナノ粒子の間質透過性も重要となる。しかし，当然のこと 


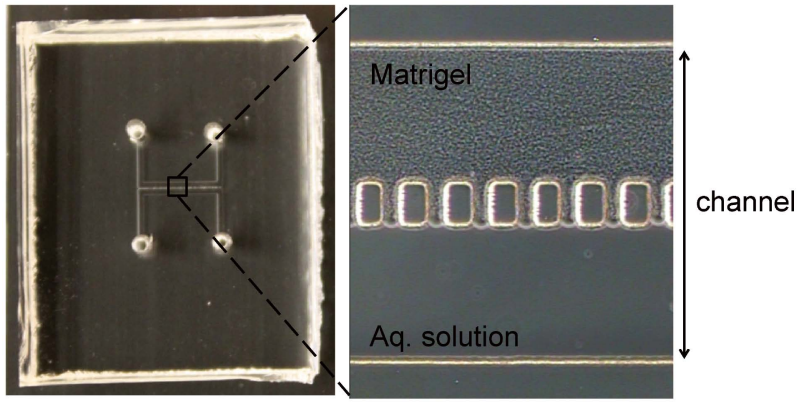

Fig. 7 Photographs of the microfluidic device Reproduced with permission from Ref. 28.

ではあるが, 生体内における間質の組成や構造は複雑であ り, これらがナノ粒子の透過に与える影響を精密評価する ことは困難である，そこで本研究では，間質のモデルとな る物質をマイクロ流路内に配し, ナノ粒子の透過性を評価 することとした．

\section{$5 \cdot 2$ 実験及び結果}

間質のモデル物質として, マウス肉腫からの抽出物であ るマトリゲルを用いることとした．これをピラー構造を有 するマイクロ流路の一部に充填し（Fig. 7)，ナノ粒子が懸 濁液中からマトリゲル中へ透過する様子を観察した，観察 手法には, 動物実験や臨床診断で広く用いられる磁気共鳴 画像化法（MRI）を用いることとした. 試料として，ガド リニウム（Gd）錯体, $\mathrm{Gd}$ 標識デキストランを用い, 透過 の様子を観察した. 結果を Fig. 8 に示す. 時間経過ととも に, マトリゲルの充填された部分からの信号強度が増大し (Fig. 8A, B)，粒子サイズが大きくなるほど信号強度の増 加速度が減少した (Fig. 8C)。これは試料の拡散係数の違 いを反映しているものと考え, 拡散係数の文献值から拡散 速度の比を求めたところ, 信号強度の増加速度の比とよく 一致することを見いだした。すなわち，本手法を用いるこ とで，ナノ粒子の間質中への拡散透過を定量評価できるこ とを示した。

$$
6 \text { 結 言 }
$$

本稿ではマイクロ流体デバイスを用いた血管モデルの構 築とその分析化学的応用について述べてきた． 細胞培養系 では, マイクロ流体デバイスを用いることで小型の培養シ ステムを構築できること, 血管と同等の環境下で物質透過 性を評価できアッセイに応用できることを示した。無細胞 系では, 多孔膜を用いてナノ粒子の透過性を精密評価でき ること, 間質のモデル物質を用いて間質内のナノ粒子透過 性を精密評価できることを示した。 これらの実験系は in vivo 分析と in vitro 分析とをつなぐ新たな生体モデルと して, 分析化学分野にとどまらず幅広く応用できる可能性
A

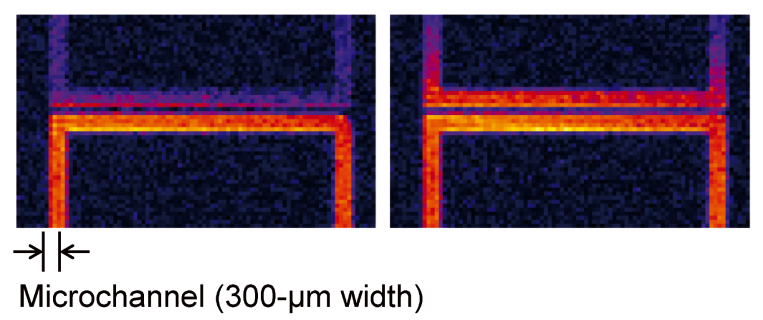

C

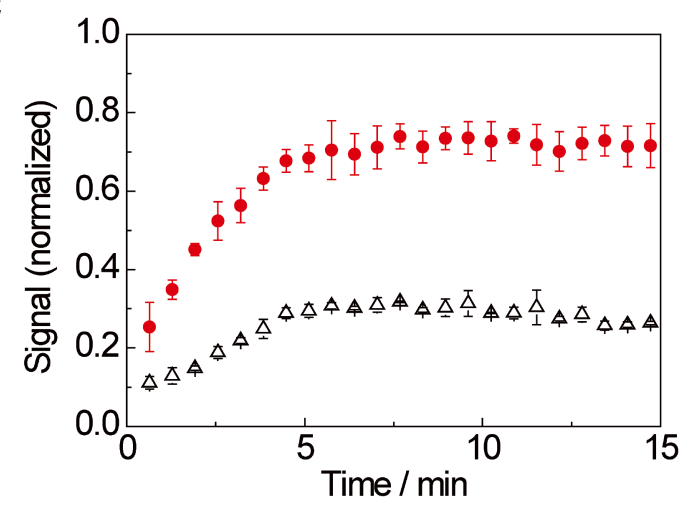

Fig. 8 Results of the MRI study

(A, B) False-color T1-weighted MRI images at (A) $t=$ $0.6 \mathrm{~min}$ and (B) $t=10.9 \mathrm{~min}$. Contrast agent: Gd-DTPA. (C) Time course of normalized MRI signal for each contrast agent. $\operatorname{Gd}$-DTPA $(N=3)$. $\triangle$ : Gd-Dex $(N=2)$. Reproduced with permission from Ref. 28.

を有している.

\section{文献}

1) S. C. Terry, J. H. Jerman, J. B. Angell : IEEE Trans. Electron Devices, 26, 1880 (1979).

2) A. Manz, Y. Miyahara, J. Miura, Y. Watanabe, H. Miyagi, K. Sato: Sens. Actuator B-Chem., 1, 249 (1990).

3) A. Manz, N. Graber, H. M. Widmer : Sens. Actuator B-Chem., 1, 244 (1990).

4) D. E. W. Patabadige, S. Jia, J. Sibbitts, J. Sadeghi, K. Sellens, C. T. Culbertson : Anal. Chem., 88, 320 (2016).

5) K. Sato, N. Sasaki, H. A. Svahn, K. Sato : Adv. Drug. Deliv. Rev., 74, 115 (2014).

6) M. Maeki, H. Yamaguchi, M. Tokeshi, M. Miyazaki : Anal. Sci., 32, 3 (2016).

7) K. Sato : Anal. Sci., 31, 867 (2015).

8) N. Kaji, Y. Baba : Anal. Sci., 30, 859 (2014).

9) 佐々木直樹: 分析化学 (Bunseki Kagaku), 64, 1 (2015).

10) 石原 量, 長谷川和貴, 細川和生, 前田瑞夫 : 分 析化学 (Bunseki Kagaku), 64, 319 (2015).

11) N. Sasaki, M. Shinjo, S. Hirakawa, M. Nishinaka, Y. Tanaka, K. Mawatari, T. Kitamori, K. Sato : Electrophoresis, 33, 1729 (2012).

12) A. L. Bowen, R. S. Martin : Electrophoresis, 31, 2534 (2010). 
13) R. Gómez-Sjöberg, A. A. Leyrat, D. M. Pirone, C. S. Chen, S. R. Quake : Anal. Chem., 79, 8557 (2007).

14) N. Futai, W. Gu, J. W. Song, S. Takayama: Lab Chip, 6, 149 (2006).

15) Y. Imura, Y. Asano, K. Sato, E. Yoshimura : Anal. Sci., 25, 1403 (2009).

16) M. Sato, N. Sasaki, M. Ato, S. Hirakawa, K. Sato, K. Sato : PLoS ONE, 10, e0137301 (2015).

17) M. R. Kano, Y. Komuta, C. Iwata, M. Oka, Y.-t. Shirai, Y. Morishita, Y. Ouchi, K. Kataoka, K. Miyazono : Cancer Sci., 100, 173 (2009).

18) M. R. Kano : Adv. Drug. Deliv. Rev., 74, 2 (2014).

19) M. E. MacDonald, R. Frayne : NMR Biomed., 28, 767 (2015).

20) G. M. Price, K. M. Chrobak, J. Tien : Microvasc. Res., 76, 46 (2008).

21) K. L. S. Chan, A. H. Khankhel, R. L. Thompson, B. J. Coisman, K. H. K. Wong, J. G. Truslow, J. Tien : J.
Biomed. Mater. Res. A, 102, 3186 (2014).

22) N. Sasaki, M. Tatanou, Y. Anraku, A. Kishimura, K. Kataoka, K. Sato : Proc. Micro Total Analysis Systems, 2013, 1818.

23) Y. Matsumura, H. Maeda: Cancer Res., 46, 6387 (1986).

24) H. Maeda, H. Nakamura, J. Fang : Adv. Drug. Deliv. Rev., 65, 71 (2013).

$25)$ B.-h. Chueh, D. Huh, C. R. Kyrtsos, T. Houssin, N. Futai, S. Takayama : Anal. Chem., 79, 3504 (2007).

26) E. W. K. Young, M. W. L. Watson, S. Srigunapalan, A. R. Wheeler, C. A. Simmons : Anal. Chem., 82, 808 (2010).

27) J. L. Anderson, J. A. Quinn : Biophys. J., 14, 130 (1974).

28) N. Sasaki, J.-i. Jo, I. Aoki, K. Sato : Anal. Biochem., 458, 72 (2014).

\title{
Analytical Applications of Microfluidic Vascular Models
}

\author{
Naoki SASAKI ${ }^{* 1}$ and Kae SATO ${ }^{2}$ \\ *E-mail : nsasaki@toyo.jp
}

${ }^{1}$ Department of Applied Chemistry, Faculty of Science and Engineering, Toyo University, 2100, Kujirai, Kawagoe-shi, Saitama 350-8585

${ }^{2}$ Department of Chemical and Biological Sciences, Faculty of Science, Japan Women's University, 2-8-1, Mejirodai, Bunkyo-ku, Tokyo 112-8681

(Received Junuary 19, 2016; Accepted March 28, 2016)

Microfluidic vascular models were utilized as a novel platform of biochemical analysis. Cellbased vascular models were developed by culturing vascular cells in microchannels. A palmtop-sized microfluidic cell culture system, consisting of a microfluidic device and a miniaturized infusion pump, was developed. The proliferation speed and protein expression of human endothelial cells cultured in the system were the same as cells in a culture flask. A microfluidic model of microcirculation containing both blood and lymphatic vessels was developed to examine the vascular permeability. The model was applied to the assay of habu snake venom, and the assay time was reduced from $24 \mathrm{~h}$ to $30 \mathrm{~min}$. On the other hand, cellfree microfluidic vascular models were developed in order to precisely understand the mechanism of microcirculation. The permeation of nanoparticles through artificial vascular walls was evaluated. The permeation of nanoparticles through interstitium surrounding the blood vessels was also evaluated under cell-free conditions. These models can bridge in vivo analysis and in vitro analysis.

Keywords: microfluidics; microcirculation; cell culture; nanoparticle; drug delivery. 